\title{
MODEL PARTICIPATORY RURAL APPRAISAL (PRA) UNTUK PEMBERDAYAAN PEREMPUAN BERBASIS PENDAMPINGAN MELALUI PELATIHAN CAKE DECORATION DI DESA BATUAN
}

\author{
Putu Eka Wirawan', A.A.A Arun Suwi Arianty ${ }^{2}$, I Gusti Ayu Melistyari Dewi ${ }^{3}$, \\ Luh Eka Susanti ${ }^{4}$, Komang Ratih Tunjung Sari ${ }^{5}$ \\ ${ }^{12345}$ Institut Pariwisata dan Bisnis Internasional, Denpasar, Indonesia \\ wirawanputu@gmail.com
}

\begin{abstract}
ABSTRAK
Desa Batuan merupakan salah satu destinasi wisata Bali yang memiliki Kawasan wisata budaya yang menawarkan permukiman tradisional. Desa Batuan merupakan jalur pariwisata menuju ke daerah wisata Ubud. Sejalan dengan perkembangan pariwisata di Kabupaten Gianyar yang mengembangkan pariwisata khususnya di bidang kuliner sebagai daya tarik wisata. Hal ini jelas dapat memberikan peluang dan ancaman bagi masyarakat Desa Batuan. Peluangnya adalah kesempatan masyarakat mendapatkan pekerjaan menjadi besar, karena adanya penyediaan pelayanan kepada wisatawan. Ancamannya, masih rendahnya pendidikan serta pengetahuan yang dimiliki oleh masyarakat lokal. Pada kesempatan ini, IPB Internasional melakukan kerjasama dengan Desa Adat Batuan Gianyar untuk memberikan pelatihan dasar perhotelan khususnya pelatihan cake decoration. Adapun pengabdian masyarakat ini dilakukan untuk meningkatkan kemampuan dan pemerdayaan kelompok wanita di Desa Batuan. Pengabdian masyarakat ini juga diharapkan akan menjadi Langkah awal kegiatan pengembangan dan pendampingan desa wisata ataupun kegiatan lain selanjutnya antara IPB Internasional dan Desa Adat Batuan Gianyar. Berdasarkan permintaan dari Desa Adat Batuan Gianyar dibutuhkan beberapa kegiatan sebagai berikut: Pelatihan cake decoration. Sasaran pokok kegiatan ini adalah IbuIbu PKK Desa Batuan sebanyak 25 orang. Dipilihnya Ibu-Ibu PKK ini didasari atas asumsi keinginan yang sangat tinggi dan adanya dorongan positif dari Bendesa Adat Desa Batuan. Memperhatikan hasil kegiatan pengabdian kepada masyarakat maka metode yang akan digunakan untuk mengatasi permasalahan dilakukan dengan metode partisipatory rural appraisal (PRA) dan metode knowledge transfer.
\end{abstract}

Kata Kunci: Model Participatory Rural Appraisal, pelatihan cake decoration, Pemberdayaan Perempuan

\section{PENDAHULUAN}

Sektor pariwisata di Indonesia saat ini dinilai efektif perannya dalam menambah devisa negara. Industri Pariwisata merupakan mata rantai ekonomi yang panjang (Multiplier effect), mulai dari biro perjalanan, jasa pengangkutsn, perhotelan, restoran, kegiatan pemanduan, kerajinan rakyat, pemeliharaan objek wisata dan lain sebagainya. Selanjutnya industri pariwisata juga akan membutuhkan hasil pertanian, peternakan, perikanan bahan dan alat bangunan, sejumlah tenaga kerja juga dapat diserap didalamnya sebagai pendukung keberhasilan mata rantai tersebut (Spillane, 1987).

Berkembangnya sector pariwisata secara tidak langsung tidak terlepas dari kajian mengenai kuliner saat ini menjadi cukup populer untuk para peneliti lokal 
maupun internasional dalam perspektif yang berbeda. Budaya kuliner di Ubud justru menjadi kuat akibat pariwisata. Perkembangan wisata kuliner di Ubud dalam kaitannya dengan perkembangan pariwisata di Ubud, bahkan Ubud merupakan sebuah desa yang sejak dulu dikenal sebagai daerah wisata budaya dan sudah terkenal di seluruh Dunia.

Cooking class atau kelas memasak merupakan tren aktivitas wisata yang tengah berkembang di dunia pariwisata. Makanan kini tidak hanya merupakan bahan pangan untuk dikonsumsi. Makanan dan minuman dalam pariwisata telah diakui sebagai subjek penting dalam penelitian, bahkan makanan dan minuman kini dilihat sebagai karakter dan budaya sebuah destinasi. Tiap-tiap destinasi memiliki masakan yang merupakan citra dari destinasi itu sendiri, sebagai contoh Italia dengan pasta dan pizza, Jepang dengan sushi dan sashimi serta Meksiko dengan tacos dan fajitas. Makanan merupakan estetika yang menjadi bagian dari budaya suatu destinasi. Wisatawan dapat menikmati estetika makanan dan minuman dalam beragam cara, seperti berkunjung ke restoran lokal, festival, pasar, dan kelas memasak (Hall dan Sharples, dalam Redl, 2013) seperti yang ada di Ubud.

Di era teknologi seperti saat ini, dimana keindahan makanan dapat dengan mudah dibagikan ke ruang publik dan diakses oleh siapa saja membuat manusia berlomba-lomba untuk mencoba makanan yang tidak hanya enak, namun juga indah dipandang dari segi visual. Perubahan gaya hidup masyarakat sedikit banyak juga mengarahkan wisatawan untuk mencoba makanan baru yang lebih sehat. Usaha-usaha pariwisata kini semakin berkembang untuk mengimbangi tren baru dalam dunia pariwisata ini (Adiprana, 2017).

Desa batuan sebagai salah satu destinasi wisata Bali yang merupakan salah satu Kawasan wisata budaya uang menawarkan permukiman tradisional. Hal ini bisa dilihat dari permukiman tradisional Bali merupakan suatu tempat kehidupan yang utuh dan bulat yang berpola tradisional yang terdiri dari 3 unsur yaitu: unsur kahyangan tiga, unsur krama desa dan karang desa dengan latar belajang normanorma dan nilai-nilai tradisional yang melandasinya (Ngakan, 2003).

Perkembangan pariwisata yang dilakukan di Desa Batuan lebih menekankan pada aspek pelestarian lingkungan. Berdasarkan observasi yang telah dilakukan bahwa pemanfaatan lahan yang digunakan untuk mendukung kegiatan pariwisata sangat terbatas seperti akomodasi, restoran, serta sarana pendukung pariwisata lainnya. Pengembangan pariwisata yang dilakukan oleh masyarakat lokal di Desa Batuan lebih menekankan pada pelestarian budaya dan pemberdayaan masyarakat lokal, hal ini bisa dilihat dari masih menjaga keaslian dari budaya dan kehidupan masyarakat lokal yang menonjolkan keaslian kehidupan masyarakat Desa Batuan.

Salah satu mata pencaharian masyarakat Desa Batuan adalah usaha melukis dan membuat patung. Usaha tersebut sudah dilakukan sejak lama dan secara turun temurun dengan harapan, menambah pendapatan ekonomi keluarga. Perkembangan era globalisasi yang menuntut masyarakat lokal ingin berkembang sesuai dengan perkembangan jaman membuat sesuatu perubahan baru. Adanya pemberian pengetahuan dan keterampilan dalam mengolah makanan western akan banyak membantu masyarakat lokal dalam mengembangkan diri dan memiliki bekal pengetahuan dan keterampilan dan pada akhirnya menjadi pendapatan dan sangat membantu ekonomi keluarga, karena terjadi penguatan ekonomi (Arina Mustafidah, 2017). 
Pembangunan sarana pariwisata seperti villa, restaurant maupun sarana pariwisata lainnya terutama di Desa Batuan belum dapat secara maksimal di ketahui oleh wisatawan. Pada saat observasi di sebuah restaurant, pengelola dan masyarakat lokal yang berada disana masih belum optimal di dalam mengolah makanan terutama western food sebagai suatu daya jual yang mampu menarik minat wisatawan untuk berkunjung ke restaurant tersebut serta didalam menyajikan makanan masyarakat lokal belum paham mengenai cara penggunaan alat makan sebagai tata cara makan yang baik dan benar.

Ketersediaan bahan pangan di Desa Batuan sangat mudah untuk didapat, namun keterampilan masyarakat di dalam mengolah bahan tersebut perlu diberikan suatu pelatihan agar makanan tersebut dapat menjadi layak jual serta terobosan atau inovasi makanan western yang lebih modern dan kreasi yang menarik (Suyastiri, 2008).

Pengabdian masyarakat merupakan salah satu dari Tri Dharma Pendidikan Tinggi yang merupakan kegiatan wajib yang harus dilaksanakan oleh seluruh perguruan tinggi di Indonesia. Hal ini juga tercantum dalam Undang-Undang Nomor 20 Tahun 2003 tentang Sistem Pendidikan Nasional Pasal 20. Dimana juga sejalan dengan penyelenggaraan kegiatan pengabdian masyarakat tersebut, dalam Undang-Undang Nomor 12 Tahun 2012 tentang Pendidikan Tinggi Pasal 45 juga menegaskan bahwa penelitian di perguruan tinggi diarahkan untuk mengembangkan ilmu pengetahuan dan teknologi, serta meningkatkan kesejahteraan masyarakat dan daya saing bangsa. Juga dijelaskan dalam pasal tersebut bahwa pengabdian masyarakat merupakan sebuah kegiatan bagi sivitas akademika dalam mengamalkan dan membudayakan ilmu pengetahuan dan teknologi untuk memajukan kesejahteraan umum dan mencerdaskan kehidupan bangsa. Salah satu bentuk pengabdian masyarakat yang akan dilakukan oleh Institut Pariwisata dan Bisnis Internasional adalah melakukan pelatihan keterampilan dasar perhotelan. Adapun tujuan dari kegiatan tersebut adalah untuk memperluas wawasan serta pengetahuan dan keterampilan civitas akademika IPB Internasional, juga sebagai implementasi ilmu pengetahuan yang telah dihasilkan oleh kampus IPB Internasional dari proses pembelajaran dan hasil penelitian.

Pada kesempatan ini, IPB Internasional akan melakukan kerjasama dengan Desa Adat Batuan Gianyar untuk memberikan pelatihan dasar perhotelan khususnya pelatihan cake decoration. Adapun pengabdian masyarakat ini dilakukan untuk meningkatkan kemampuan dan pemerdayaan kelompok wanita di Desa Batuan. Pengabdian masyarakat ini juga diharapkan akan menjadi Langkah awal kegiatan pengembangan dan pendampingan desa wisata ataupun kegiatan lain selanjutnya antara IPB Internasional dan Desa Adat Batuan Gianyar.

Berdasarkan permintaan dari Desa Adat Batuan Gianyar dibutuhkan beberapa kegiatan sebagai berikut: Pelatihan cake decoration. Adapun peserta dari pengabdian masyarakat yang akan dilaksanakan adalah kelompok ibu-ibu PKK Desa Adat Batuan.

Partisipasi merupakan elemen penting dalam penyelenggaraan pengabdian dan pelatihan pada era globalisasi (Gaventa, 2005) dan pada kegiatan tersebut itu diperlukan metode yang efektif untuk menumbuhkan partisipasi masyarakat yang tinggi. PRA merupakan perpanjangan dan penerapan dari pemikirian, pendekatan, dan pelatihan, terutama menyangkut konsep mengenai pembelajaran yang fleksibel di lapangan, nilai penting dari observasi-partisipasi, pentingnya pendekatan 
(rapport), pembedaan cara pandang etik (cara pandang peniliti) dan emik (cara pandang anggota komunitas), serta validitas dari pengetahuan lokal (Chambers, 1994:955).

Adapun tujuan kegiatan pengabdian yang dilakukan adalah sebagai berikut:

a. Mengembangkan sekelompok masyarakat yang mandiri secara ekonomi

b. Meningkatkan kemampuan pengetahuan tentang cake decoration dalam penyajian secara Internasional.

c. Meningkatkan kemampuan dalam mengolah makanan yang telah ada sebelumnya sehingga memiliki inovasi dan kretifitas baru.

d. Meningkatkan ketrampilan dasar pengembangan produk makanan di Desa Batuan

Adapun tujuan kegiatan pengabdian yang dilakukan adalah sebagai berikut:

a. Diperolehnya pemahaman akan prospek peluang dan tantangan dalam cake decoration.

b. Tersedianya SDM yang andal di bidang cake decoration

c. Diperolehnya ketrampilan pengolahan bahan makanan menjadi suatu inovasi yang baru yang dapat dijual

d. Menumbuhkan semangat kewirausahaan dikalangan masyarakat.

\section{METODE}

Sasaran pokok kegiatan ini adalah Ibu-Ibu PKK Desa Batuan sebanyak 25 orang. Dipilihnya Ibu-Ibu PKK ini didasari atas asumsi keinginan yang sangat tinggi dan adanya dorongan positif dari Bendesa Adat Desa Batuan. Memperhatikan hasil kegiatan pengabdian kepada masyarakat maka metode yang akan digunakan untuk mengatasi permasalahan dilakukan dengan metode partisipatory rural appraisal (PRA) dan metode knowledge transfer.

Metode PRA menjadi himpunan pendekatan yang memungkinkan masyarakat desa untuk saling berbagi mengembangkan dan menganalisa pengetahuan mereka mengenai hidup dan kondiri mereka sendiri untuk sebuah perencanaan yang lebih matang delam era globalisasi (Chambers, 1994:953). Salah satu metode dari puluhan metode yang dikembangkan melalui PRA adalah participatory planning (perencanaan secara partisipatoris), yang disertai penganggaran (budgetting), implementasi, dan evaluasi. Melalui metode ini, masyarakat lokal mempersiapkan diri mereka, jadwal pendampingan, melakukan aksi, serta melakukan monitoring dan evaluasi. Proses inilah yang disebut dan menghasilkan CAP (Community Action Plan).

Melalui metode PRA, masyarakat desa bukan lagi sebagai objek yang menerima program dari atas (top-down), melainkan menjadi subjek pembangunan yang merancang program pembangunan dari bawah (bottom-up) dengan terus aktif dalam proses perencanaan, penentuan skala prioritas program, penganggaran, pelaksanaan, dan pemanfaatan hasil pembangunan yang dikendalikan di tingkat desa. Partisipasi warga yang tinggi dalam proses pembangunan skala desa menjadikan program dapat dilaksanakan berbasis pada keswadayaan dan dapat lebih berhasil guna kesejahteraan mereka. 
Posisi peneliti dalam PRA adalah sebagai fasilitator, yaitu orang yang memudahkan masyarakat untuk melakukan penelitian aksi tersebut. Melalui partisipasi yang tinggi, warga masyarakat yang terlibat dalam PRA dapat aktif dalam setiap kegiatan kelompok, misalnya pengumpulan data, analisis data, perumusan program, anggaran, dan detail kegiatan, serta implementasinya. Karena bertindak sebagai fasilitator, kegiatan PRA dapat dikatakan berhasil jika kelompok warga dapat aktif dan terus termotivasi untuk menghasilkan CAP serta melaksanakannya secara partisipatif. PRA merupakan metode yang sangat tepercaya untuk program pemberdayaan masyarakat (Sinha, 1997; Mikkelson, 2011). Beberapa studi telah menunjukkan efektivitas metode ini. Studi Olofson (1985), misalnya, menunjukkan bahwa PRA dapat dipakai untuk program pelestarian hutan berbasis komunitas. Das (2012) telah menggunakan PRA untuk mewujudkan pengelolaan hutan secara partsipatoris sehingga mewujudkan penghidupan masyarakat desa yang berkelanjutan.

\section{HASIL DAN PEMBAHASAN}

\section{A. Pendampingan Cake Decoration}

Berdasarkan hasil wawancara dan kesepakatan dengan Kepala Desa, Desa Adat Batuan maka program pelatihan yang dilakukan sebagai berikut:

a. Pelatihan cake decoration dengan materi pelatihan yang diberikan adalah Birthday Cake (basic pastry, basic sponge cake, cake decoration).

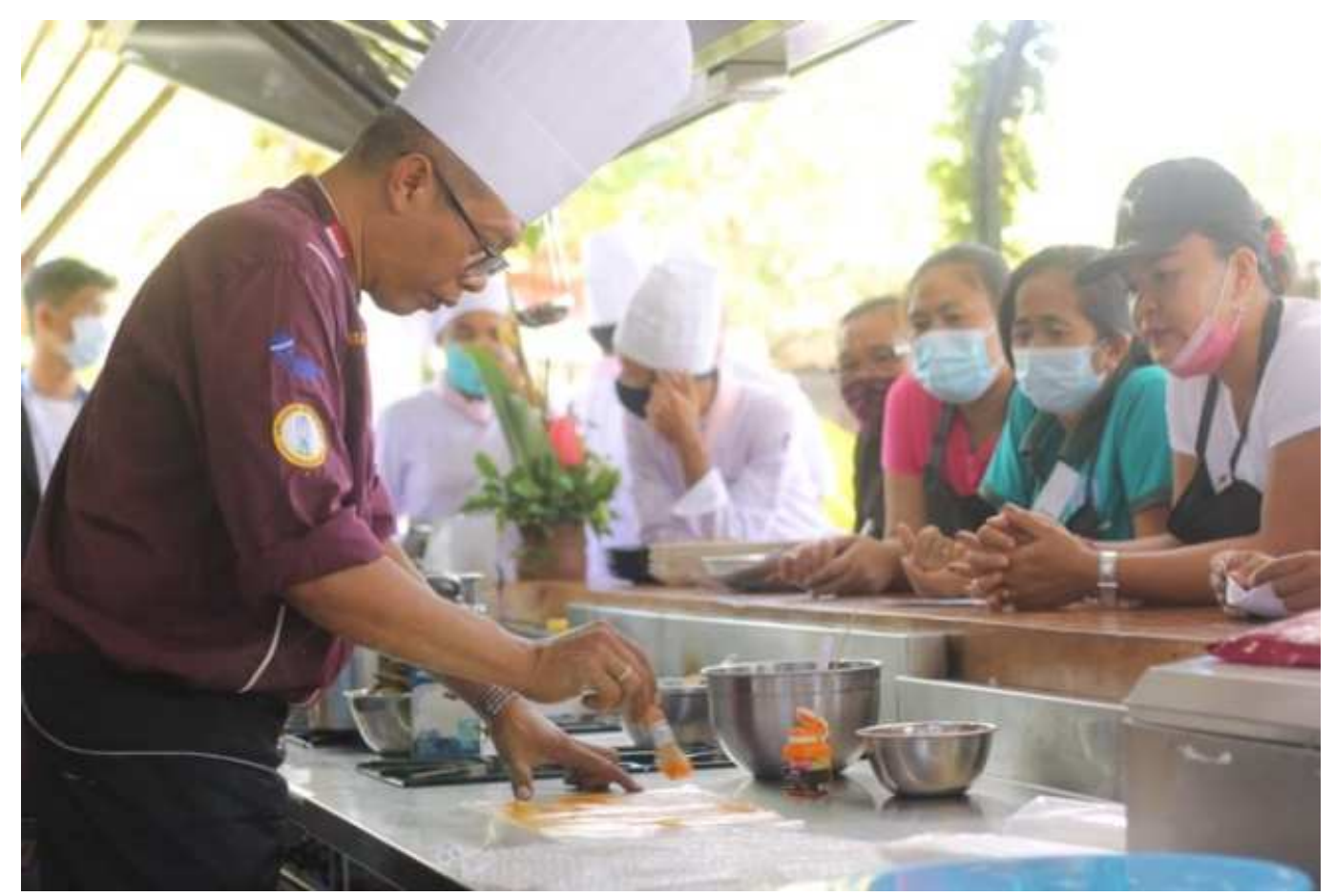

Gambar 1. Metode knowledge transfer pada pelatihan cake decoration

b. Pelatihan cake decoration dengan materi pelatihan yang diberikan adalah Gingerbread (category of baked good, typically flavoured, sweetened). 


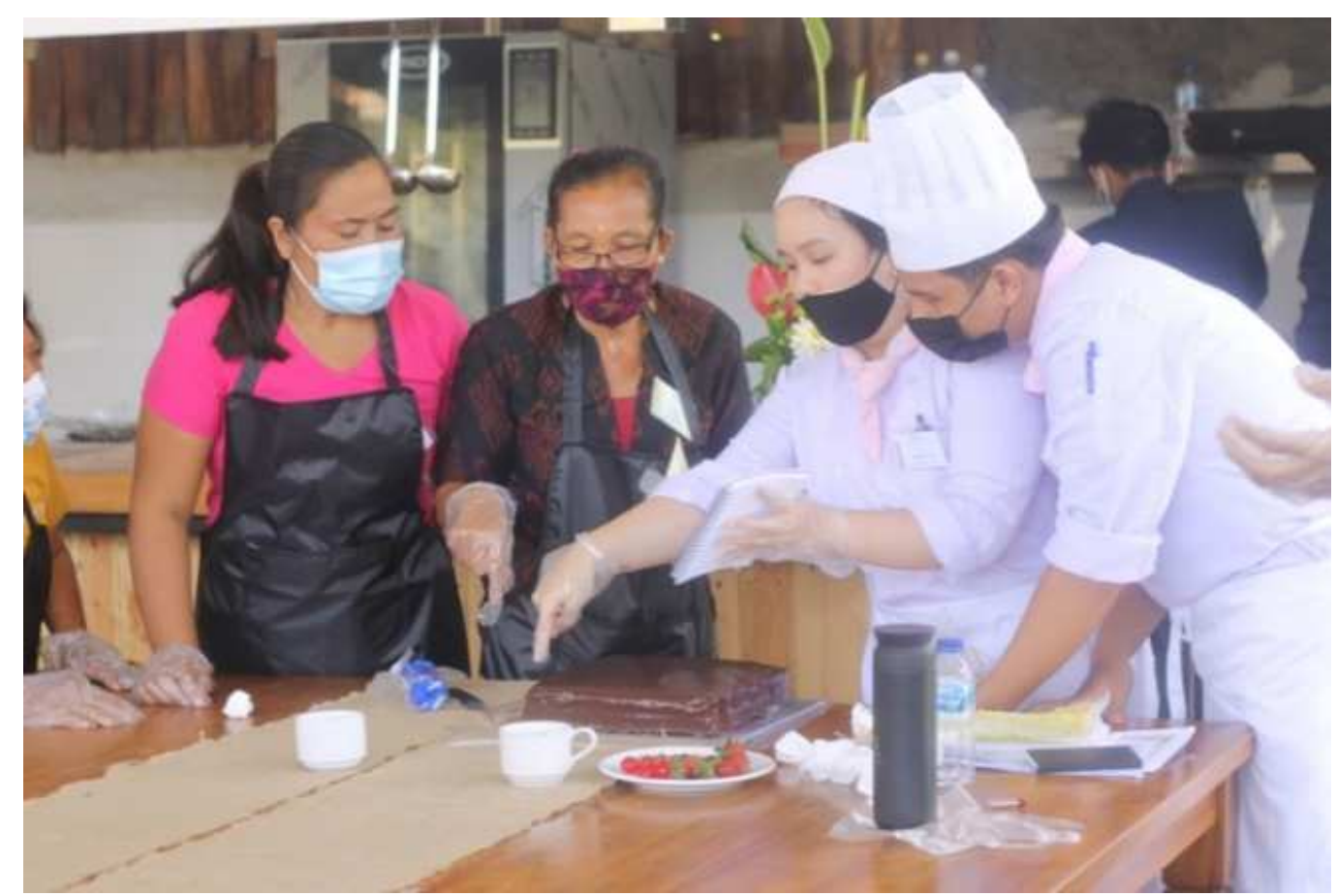

Gambar 2. Metode participatory rural appraisal pada pelatihan cake decoration

Program pelaksanaan kegiatan pengabdian ini mencakup pelatihan dan pendampingan, untuk seluruh materi diberikan oleh Bali Chef Community dan Indonesia Pastry Alliance yang terdiri dari juru masak yang sudah professional dalam bidangnya serta pendampingan juga diikuti oleh mahasiswa IPB Internasional jurusan manajemen tata boga. Pelaksanaan diadakan di Puri Astrian, Desa Batuan, Gianyar. Adapun model pelatihan dan pendampingan cake decoration ini, yaitu:

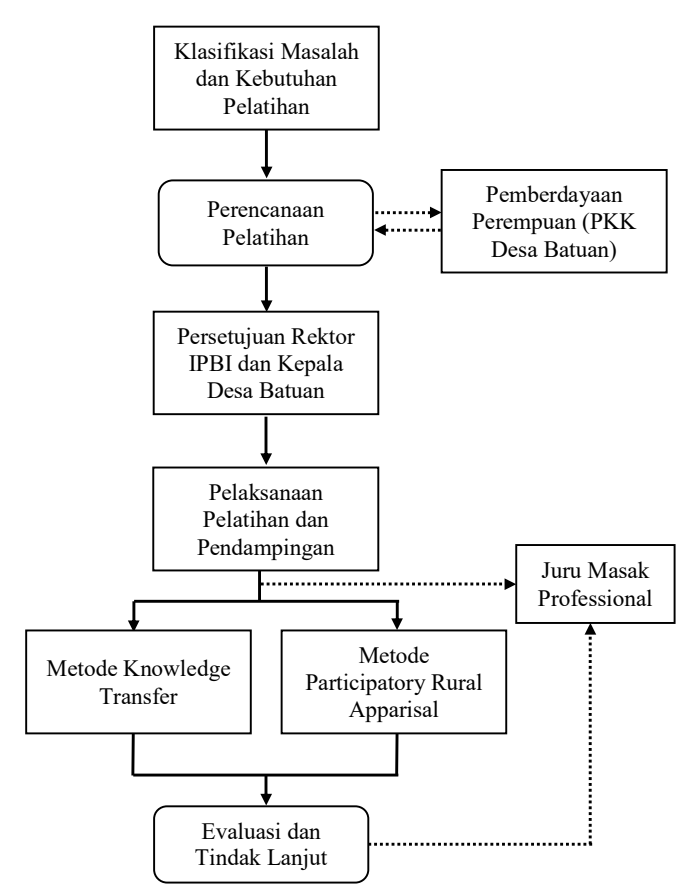

Gambar 3. Model Pelatihan dan Pendampingan Cake Decoration 
Pelaksanaan kegiatan pelatihan cake decoration ini dilaksanakan dalam ruangan yang sangat luas dan memadai sehingga peserta sangat leluasa dalam berinteraksi satu dengan lainnya. Proses pelatihan ini pertama dilakukan oleh juru masak professional di hadapan partisipan yang menyimak dengan sangat serius dan antusiasme mereka, setelah itu para partisipan melakukan praktik nyata sesuai dengan yang diberikan sebelumnya dan itu lebih disukai oleh partisipan dengan melakukan keterampilan interpersonal merupakan komunikasi yang dilakukan dalam suatu hubungan antara dua orang atau lebih, baik secara verbal maupun nonverbal, dengan tujuan untuk mencapai kesamaan bersama. Jadi keterampilan ini menekankan pada hubungan seseorang dengan individu atau grup lain. Sebagaimana kita ketahui bahwa manusia adalah makhluk sosial yang akan selalu membutuhkan orang lain, jadi penting bagi kita untuk menguasai beberapa keahliannya.

Dalam memberikan pengelolaan para juru masak professional memberikan teknik cake decoration dan ginger bread. Konsep dibalik mendesign cake adalah untuk mendesign sebuah karya seni indah yang dapat dikonsumsi dan dapat dinikmati oleh orang banyak tanpa mengingat bahwa hal tersebut adalah merupakan sebuah kue, hal ini harus menarik perhatian orang banyak dan hanya terdapat pada acara penting (Dam, 2011). Design ini bertujuan meningkatkan nilai artistic dan meningkatkan daya tarik.

\section{Evaluasi Program}

Berdasarkan hasil kegiatan pengabdian masyarakat ini diperoleh evaluasi kegiatan yang meliputi pendampingan dan evaluasi hasil. Pendampingan dilakukan sebagai persiapan cake decoration dengan memberikan penghargaan kepada kelompok yang terbaik yang diikuti oleh seluruh Ibu-Ibu PKK Desa Batuan.

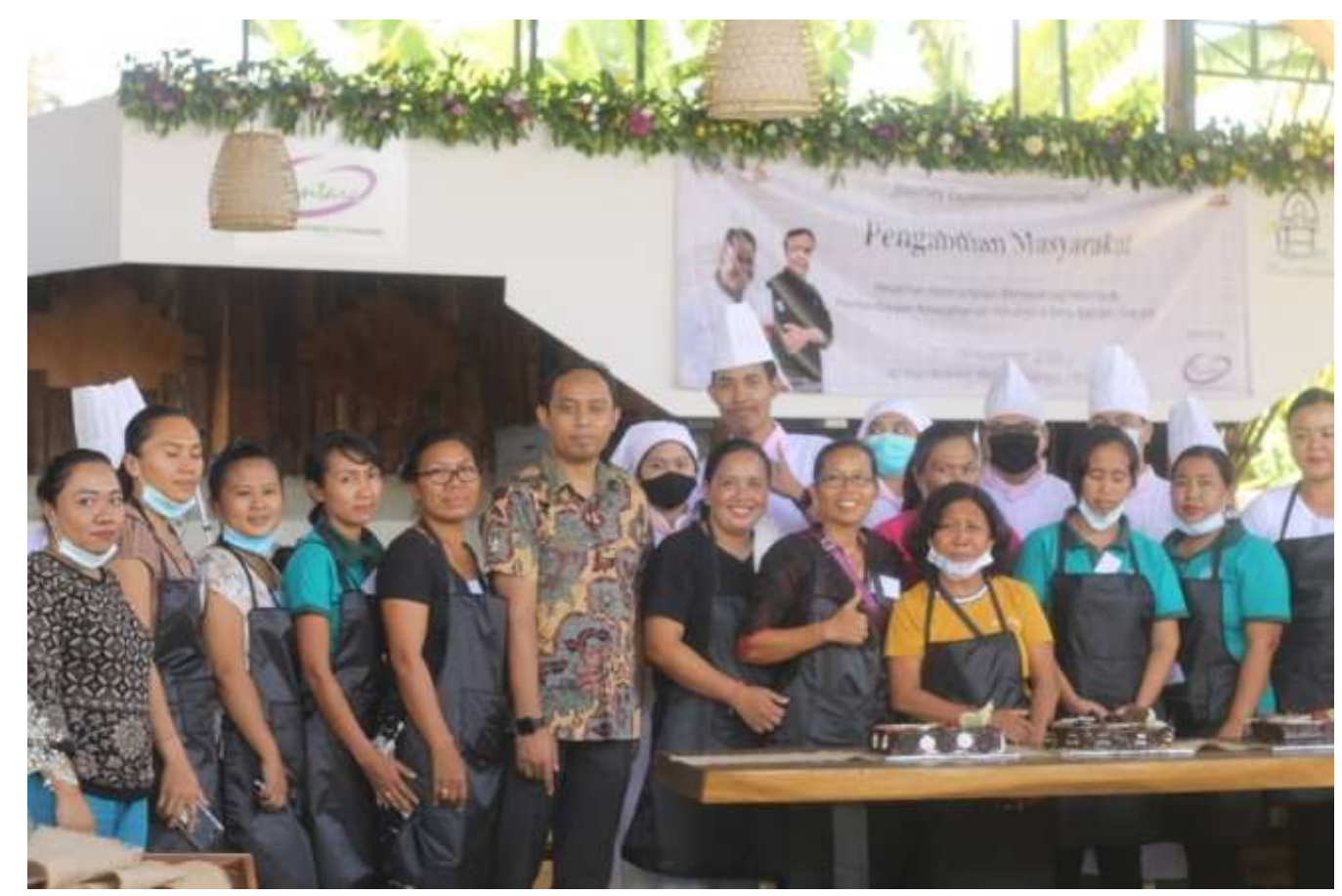

Gambar 4. Foto Bersama Pelatihan dan Pendampingan Cake Decoration di Desa Batuan, Gianyar 
Keberhasilan program pelatihan dan pendampingan cake decoration yang telah dilakukan dengan kajian secara mendalam dengan melakukan evaluasi melalui kuisioner terhadap Ibu-Ibu PKK Desa Batuan. Kegiatan pelatihan dan pendampingan cake decoration yang telah dilakukan berdasarkan evaluasi mendapatkan kategori baik dengan rata-rata penilaian peserta pelatihan dan pendampingan berdasarkan penyebaran kuisioner adalah sebesar 4,55. Untuk lebih jelas dapat dilihat pada gambar 5 .

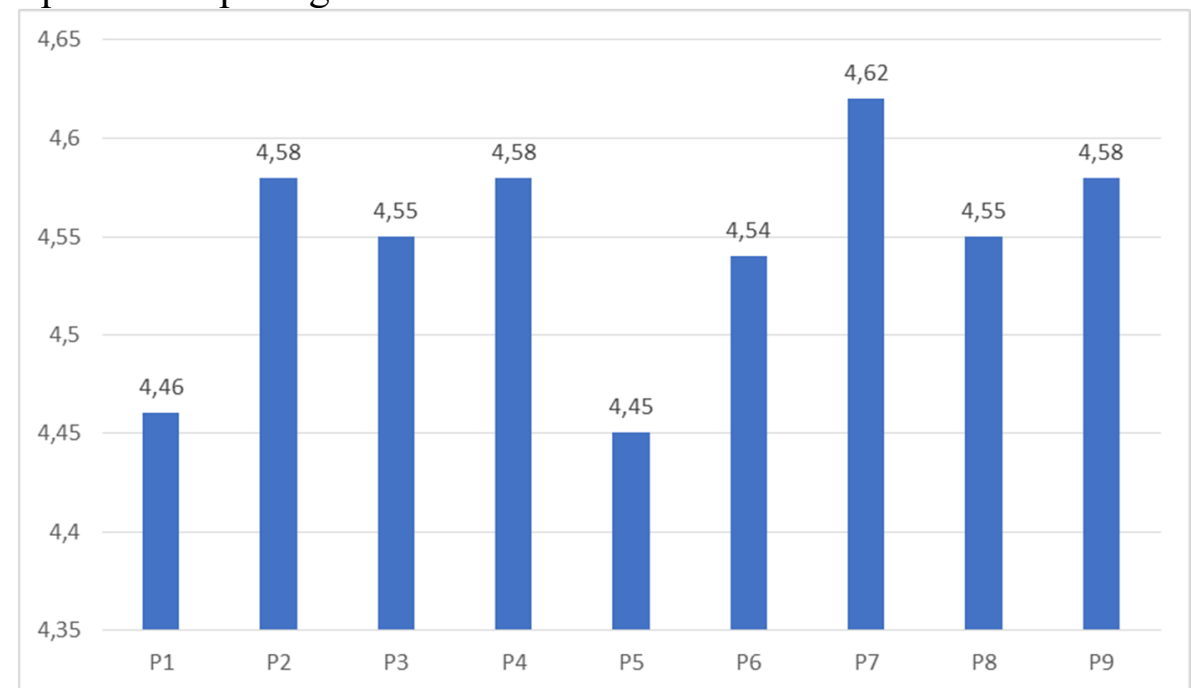

Gambar 5. Nilai Rata-rata Kuisioner Evaluasi Pelatihan dan Pendampingan Cake Decoration

Pada metode partisipatory rural appraisal (PRA) dan metode knowledge transfer ada tiga aspek pengukuran terhadap kegiatan pelatihan yaitu 1) penilaian ini materi kegiatan pelatihan, 2) penilaian transfer knowledge oleh narasumber, 2) penilaian partisipasi antar Ibu-Ibu PKK dalam kegiatan ini.

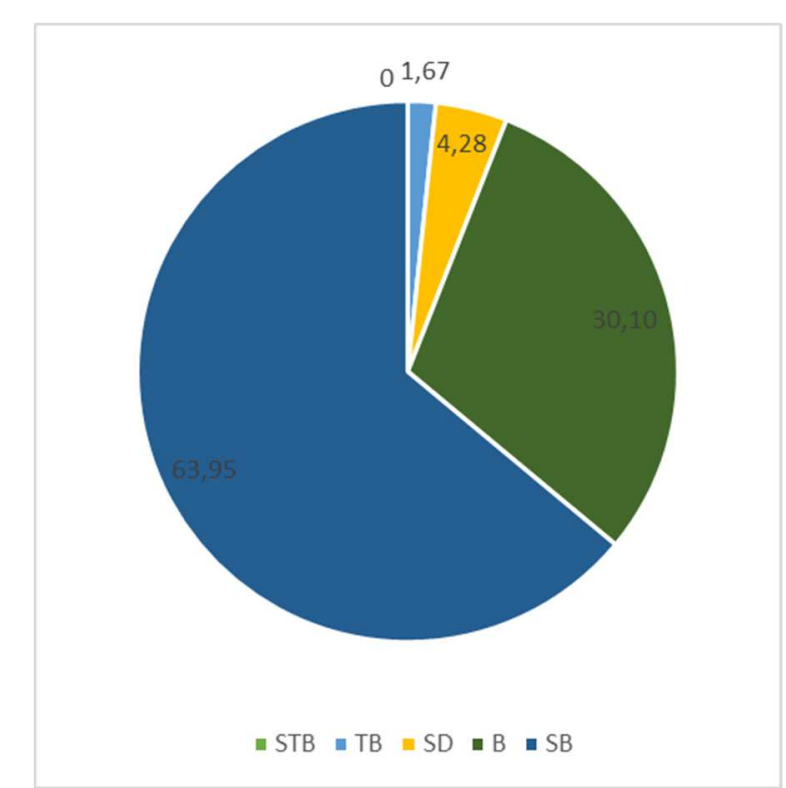

Gambar 6. Persentase Penilaian Materi Pelatihan 
Pada aspek penilaian materi pelatihan memperlihatkan bahwa 94.05\% peserta memilih kategori baik dan sangat baik. Hal ini memperlihatkan bahwa 1) materi yang dibawakan sangat terstruktur dengan baik dan mudah dipahami, 2) materi sangat relevansi sesuai dengan tujuan yang diharapkan, 3) materi yang disampaikan sudah mencakup pemahaman tentang cake decoration

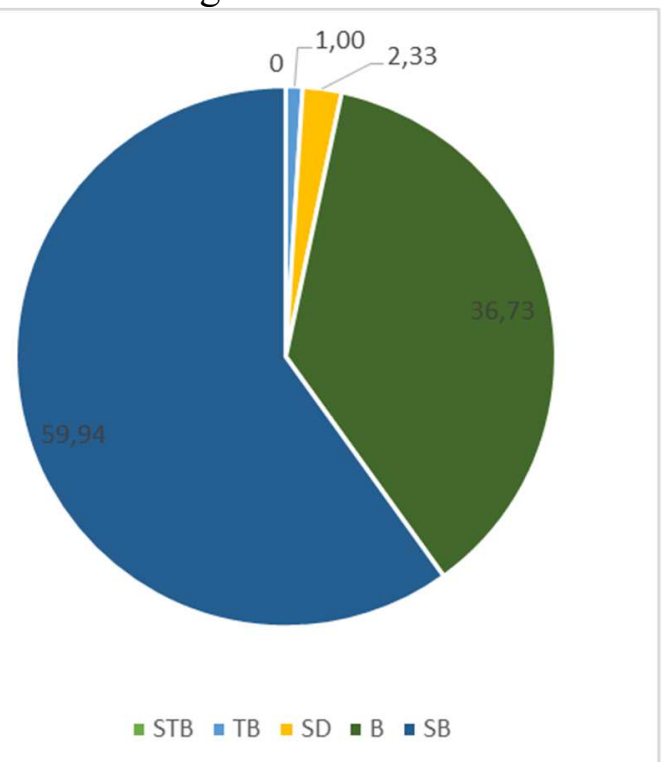

Gambar 7. Persentase Penilaian Knowledge Transfer

Pada aspek penilaian transfer/sharing knowledge materi pelatihan menunjukkan bahwa 96.67\% peserta memilih kategori baik dan sangat baik. Hal ini memperlihatkan bahwa 1) narasumber sangat interaktif dalam memberikan materi yang disampaikan, 2) adanya interaksi yang sangat baik antara narasumber dengan peserta pelatihan, 3) adanya kegiatan berbagi pengalaman antar narasumber dan peserta pelatihan sehingga materi yang disampaikan dapat diterima dengan mudah dimengerti dan diimplementasikan.

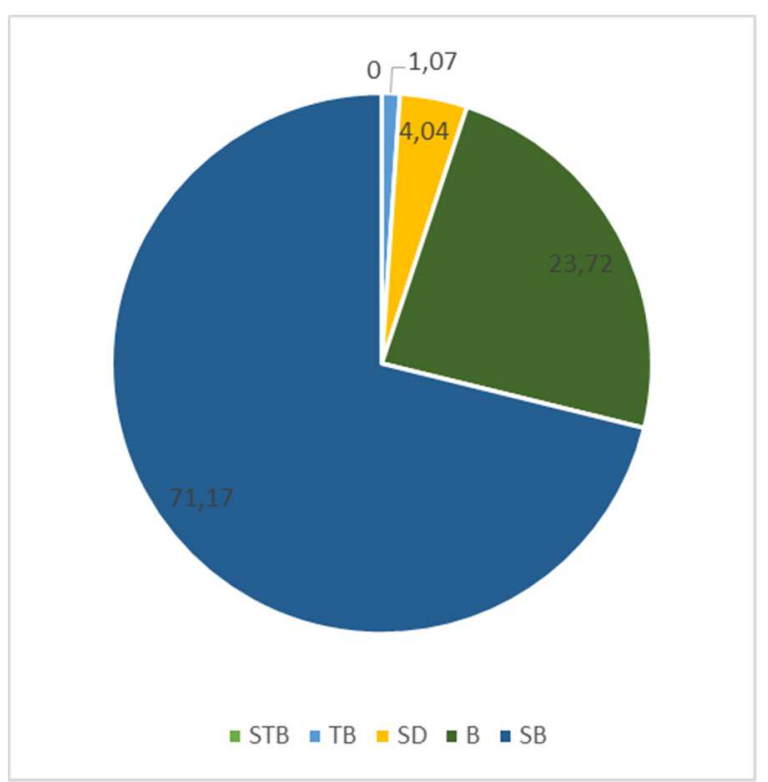

Gambar 8. Persentase Penilaian Knowledge Transfer 
Pada aspek penilaian partisipatory rural appraisal pada pelatihan memperlihatkan bahwa $94.89 \%$ peserta memilih kategori baik dan sangat baik. Hal ini memperlihatkan bahwa 1) peserta sangat aktif didalam melakukan kegiatan tersebut, 2) peserta menyelesaikan kegiatan tersebut sesuai dengan waktu yang diberikan dan memperoleh suatu kesenangan, 3) peserta mampu mempersatukan sebuah perbedaan dalam sebuah kelompok yang memberikan hasil terbaik.

\section{Dampak Program Pelatihan}

Berdasarkan hasil kegiatan pelatihan dapat terlaksana karena partisipasi masyarakat yang tinggi dengan kata lain deapat memperdayakan perempuan diperoleh dampak langsung dari program pelatihan cake decoration di Desa Batuan, Gianyar yaitu 1) meningkatkan pengetahuan Ibu-Ibu PKK Desa Batuan dalam melakukan cake decoration, 2) Ibu-Ibu PKK Desa Batuan lebih terampil kreatif dan inovatif melakukan cake decoration, 3) Ibu-Ibu PKK Desa Batuan lebih percaya diri melakukan cake decoration dan siap bersaing dalam era globalisasi.

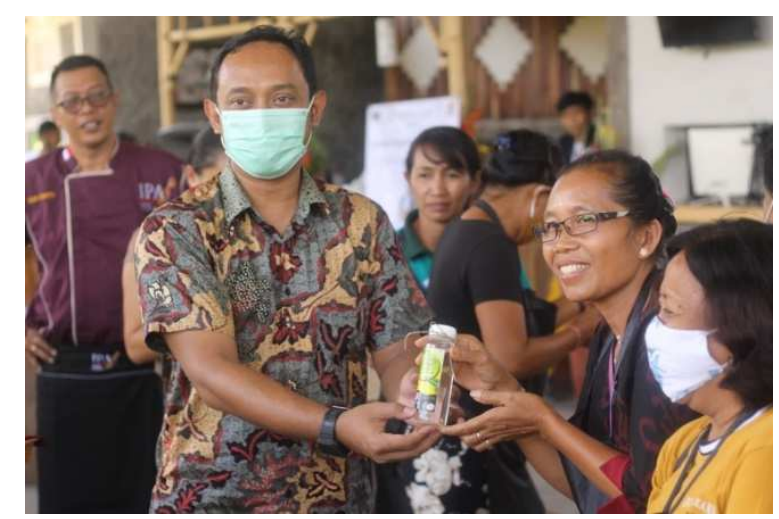

Gambar 8. Penyerahan Cinderamata kepada Ibu PKK

Berdasarkan program rintisan yang dilakukan dengan melibatkan civitas akademika untuk melakukan cake decoration di Desa Batuan, Gianyar, maka dapat disimpulkan bahwa Ibu-Ibu PKK mampu mendekorasi kue dan lebih percaya diri dengan pengetahuan dan keterampilan yang sudah diperoleh selama pelatihan dan pendampingan sehingga terciptanya gagasan baru untuk dapat lebih berinovasi dan berkreasi di masa pandemic ini.

\section{SIMPULAN}

Program pengabdian kepada masyarakat di Desa Batuan, Gianyar ini melibatkan akademisi, mahasiswa, masyarakat lokal (Ibu-Ibu PKK) yang memiliki tujuan untuk memberdayakan perempuan khususnya Ibu-Ibu PKK dalam bentuk pelatihan dan pendampingan cake decoration. Adapun dampaknya adalah 1) meningkatkan pengetahuan Ibu-Ibu PKK Desa Batuan dalam melakukan cake decoration, 2) Ibu-Ibu PKK Desa Batuan lebih terampil kreatif dan inovatif melakukan cake decoration, 3) Ibu-Ibu PKK Desa Batuan lebih percaya diri melakukan cake decoration dan siap bersaing dalam era globalisasi. Pelaksanaan program pelatihan dan pendampingan tahun 2020 ini telah dilaksanakan dengan baik dan lancar serta memberikan manfaat bagi kemajuan khususnya keterampilan Ibu-Ibu PKK dalam menghias kue. 


\section{UCAPAN TERIMAKASIH}

Puji syukur kehadapan Tuhan Yang Maha Esa atas karunia-Nya yang telah diberikan, sehingga dapat menyelesaikan program pengabdian kepada masyarakat melalui pelatihan dan pendampingan Ibu-Ibu PKK di Desa Batuan, Gianyar. Ucapan terimakasih disampaikan kepada Rektor Institut Pariwisata dan Bisnis Internasional yang sudah memberikan motivasi terhadap kelancaran kegiatan pengabdian kepada masyarakat ini. Ucapan terimakasih juga disampaikan terhadap Kepala Desa Batuan Gianyar atas kepercayaan dan segala fasilitas selama kegiatan pengabdian masyarakat.

\section{DAFTAR PUSTAKA}

Adiprana, 2017. Ekspektasi Dan Persepsi Wisatawan Terhadap Kuliner Lokal di Ubud. Tesis Kajian Pariwisata Universitas Udayana

Arina, M., 2017. Pelatihan Pengolahan Makanan Tradisional Untuk Meningkatkan Potensi Kreasi Olahan Basah Singkong di Desa Gayamharjo Prambanan Sleman. Jurnal Bakti Saintek, I(2), pp. 79 - 83.

Chambers, R., 1996. "PRA (Participatory Rural Appraisal) Memahami Desa Secara Partisipatif”. Yogyakarta: Penerbit Kanisuis.

Das, P.K. \& Mondal, A.K., 2012, Studies on Traditional 'Mehendi' used as Herbal Colour with Special References to its Antimicrobial Activity and Pigment Profile by TLC, International Journal of Science and Nature, 3 (4), p799804.

Gaventa, J., \& Valderrama, C., 1999. Participation, Citizenship and Local Governance Background. Workshop on Strengthening participation in local governance. Institute of Development Studies, pp. 21-24.

Hall, C. M., Sharples, M., Macionis \& Brock C., 2003. Food Tourism Around The World: Development, Management, and Markets. UK: ButterworthHeinemann Elsevier Ltd.

Mikkelson, B. 2011. Metode Penelitian Partisipatoris. Jakarta; PT Gramedia

Ngakan, 2003. Perumahan dan Permukiman Tradisional Bali. Jurnal Permukiman "Natah", I(1).

Mustafidah, A., 2017. Pelatihan Pengolahan Makanan Tradisional Untuk Meningkatkan Potensi Kreasi Olahan Basah Singkong di Desa Gayamharjo Prambanan Sleman. Jurnal Bakti Saintek: Jurnal Pengabdian Masyarakat Bidang Sains dan Teknologi. I(1), pp. 79-83.

Olofson, H., 1985. Traditional Agroforestry, parcel management, and social forestry development in a pioneer agricultural community: the case of Jalajala, Rizal.

Spillane, J.J., 1987. Pariwisata Indonesia Sejarah dan Prospeknya. Yogyakarta: Kanisius.

Suyastri, 2008. Diversifikasi Konsumsi Pangan Pokok Berbasis Potensi Lokal Dalam Mewujudkan Ketahanan Pangan Rumah Tangga Di Kecamatan Semin Kabupaten Gunung Kidul. Jurnal Ekonomi Pembangunan Volume 13 Nomor 1 April 2008. Universitas Veteran. Yogyakarta.

Suyastiri, N M., 2008. Diversifikasi Konsumsi Pangan Pokok Berbasis Potensi Lokal dalam Mewujudkan Ketahanan Pangan Rumah Tangga Pedesaan Di Kecamatan Semin Kabupaten Gunungkidul. Jurnal Ekonomi Pembangunan, XIII(1), April 2008. pp. 51-60. 